\title{
The Influence of Displacement Distance and Vision on the Homing Behavior of the White-Footed Mouse (Peromyscus leucopus Noveboracensis)
}

Judith Ann Cooke

College of William \& Mary - Arts \& Sciences

Follow this and additional works at: https://scholarworks.wm.edu/etd

Part of the Social and Behavioral Sciences Commons

\section{Recommended Citation}

Cooke, Judith Ann, "The Influence of Displacement Distance and Vision on the Homing Behavior of the White-Footed Mouse (Peromyscus leucopus Noveboracensis)" (1975). Dissertations, Theses, and Masters Projects. Paper 1539624888.

https://dx.doi.org/doi:10.21220/s2-5416-mb95

This Thesis is brought to you for free and open access by the Theses, Dissertations, \& Master Projects at W\&M ScholarWorks. It has been accepted for inclusion in Dissertations, Theses, and Masters Projects by an authorized administrator of W\&M ScholarWorks. For more information, please contact scholarworks@wm.edu. 
THE INFLUENCE OF DISPLACGMENT DISTANCE AND VISION 11

ON THE HOMING BEHAVIOR OF THE WHITE-FOOTED MOUSE

(PEROMYSCUS IEUCOPUS NOVEBORACENSIS)

\begin{abstract}
A Thesis
Presented to the

Faculty of the Department of Biology

The College of William and Wary in Virginia
\end{abstract}

In Partial Fulfillment of

The Requirements for the Degree of

Master of Arts

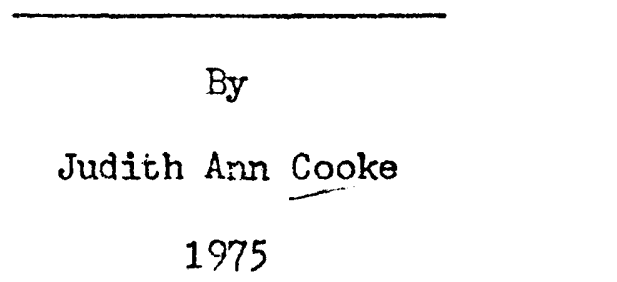


APPROVAL SHEET

This thesis is submitted in partial fulfillment of the requirements for the degree of Master of Arts

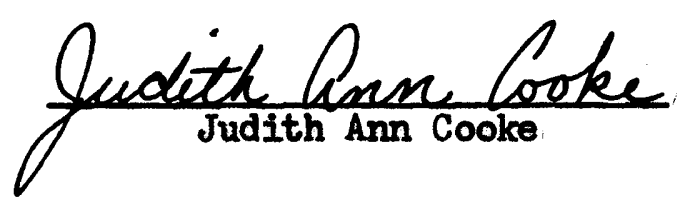

Approved, January 1975
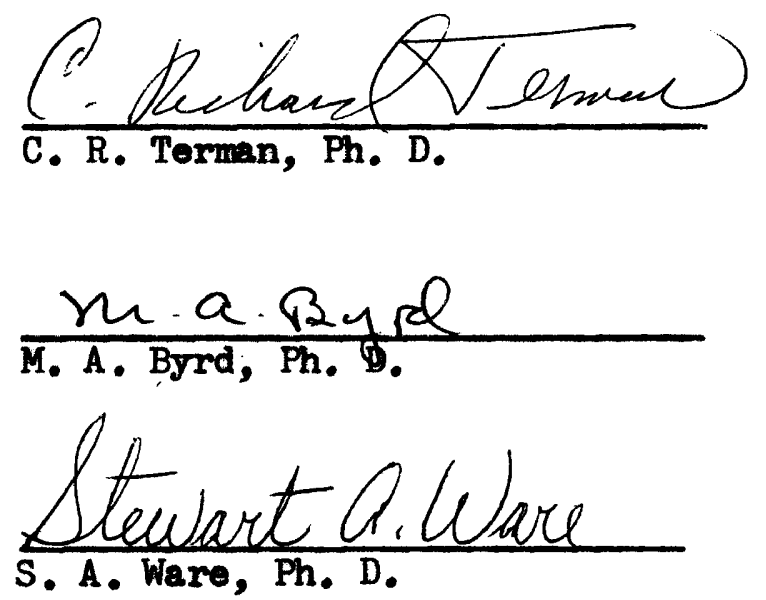

617378 
TABLE OF CONTENTS

Page

ACKNOWLEDGMENTS . . . . . . . . . . . . . . . . iv LIST OF TABLES .................... v LIST OF FIGURES . . . . . . . . . . . . . . . vii ABSTRACT .... ..... . ............ viil INTRODUCTION . . . . . . . . . . . . . . . 2 THE STUDY AREA . . . . . . . . . . . . . . . 4 GENERAI PROCEDURES ..... . . . . . . . . 6 SPECIFIC EXPERIMENTAL PROCEDURES AND RESULTS . . . . . 8 EFFECTS OF VARIABLES .............. 17 POPULATION DESCRIPTION . . . . . . . . . . . 29 DISCUSSION . . . . . . . . . . 43 REFRENCES CITED . . . . . . . . . . . 51 
ACKNOWIEDGEMENTS

I wish to thank Dr. C. Richard Terman for his suggestions and guidance throughout this study. I am also grateful to Dr. Stewart Ware for the description of the vegetation in my study areas, and for his critical review of the manuscript. I am indebted to Dr. Mitchell A. Byrd for serving on the committee and for reviewing the manuscript. 
LIST OF TABLES

Table

Page

1. Dates of the beginning and the end of each trapping period . . . . . . . . . . 9

2. Recapture data for each period of the five experiments • . . . . . . . . 13

3. Number of mice released and recaptured during the seven day recapture phase of each period of the five experiments . . . . 18

4. Numbers of mice relessed and recaptured during the last three days of the appropriate period of Experiment II and Experiment IV .

5. Numbers of adults, subadults and juveniles captured on Plot I and PIot II during each trapping period . . . . . . . 23

6. Numbers of males and females captured on Plot I and Plot II during each period . . . . 24

7. Reproductive rate of the combined populations of

Plot I and Plot II during each period . . 25

8. Numbers of mice captured on PIot I and on PIot II during each period . . . . . 30

9. Effect of repeated transfer on success of homing - 31 
Table

in Experiment III

10. Homing performances of adults, subadults and

juveniles relessed during Experiment

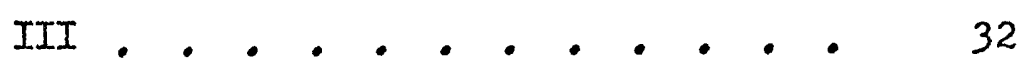

11. Homing performances of males and females in

Experiment III •. . • • . . 33 
IIST OF FIGURES

Figure

Page

1. Aerial view of the study areas . . . . . 10

2. Numbers of adults, subadults, and juveniles

captured on Plot I and Plot II during

the ten trapping periods. . . . 20

3. Numbers of males and females captured on Plot I and

Plot II during each trapping period. . . 26

4. Reproductive rate of the combined $\underline{P}$. leucopus

populations on Plot I and PIot II . . 34

5. Number of mice captured on PIot I and on PIot II

duxing each period - . - . . 36

6. Numbers of males and females captured on Plot I and PIot II during each period. . . . 39

7. Cumulative percentage curve of the rate of recapture of experienced and naive mice

released from the midpoint . . . 41 
ABSTRACT

The purpose of this experiment was to determine the degree to which Peromyscus leucopus noveboracensis would home when displaced, the effect which distance had upon homing, and whether vision was involved to a significant degree in the process of return. Aninals were removed from two study areas during an eight night removal phase, then released. Three different release points were used during the five experinents. Return was determined by live-trapping during the next seven nights (recovery phase). Ten replications of this manipulation were conducted over six months.

These animals were capable of returning to their home plots in numbers higher than can be explained by random wanderIng when released midway between plots ( a displacement distance of 336 meters ). However, when released on the plot opposite from that of capture ( 671 meters), they did not home significantly different than expected by chance. Thus the homing success was distance dependent though factors such as the release area habitat may have been involved.

When released on their plot of capture, the homing success of blinded mice was not significantly different than that of intact mice treated similarly. However, when released miciway between plots, a significantly smaller proportion of blinded mice than of intact mice homed. The possible reasons for this differential response to the loss of vision are discussed. 
THE INFLUENCE OF DISPIACEMENT DISTANCE AND VISION ON THE HOMING BEHAVIOR OF THE WHITEFOOTED MOUSE (PEROMYSCUS IEUCOPUS NOVEBORA-

CENSIS) 


\section{INTRODUCTION}

Homing, the ability to return to a locality when displaced, has been demonstrated among such rodents as the meadow mouse, Microtus pennsylvanicus (Robinson and Falls 1965), chipmunk, Tamias striatus lysteri (Burt 1940, Layne 1954), flying squirrel, Glaucomys v. volans (Macabe 1947), St. Kilda field mouse, Apodemus sylvaticus hirtensis (Boyd 1963), California vole, Microtus californicus (Fisler 1962), Western harvest mouse, Reithrodontomys megalotis (Fisler 1966), Oldficld mouse, Peromyscus polionotus (Gentry 1964), Cotton mouse, Peromyscus gossypinus (Griffo 1961), deermouse, Peromyscus maniculatus (Murie and Murie 1931, 1932, Broadbrooks 1961, Murie 1963, Bovet 1968, 1971, 1972, Terman 1962, and Furrer 1973), and the white-footed mouse, Peromyscus leucopus (Stickel 1949, and Sheppe 1965).

Four explanations of the means by which rodents successfully home have been suggested. Robinson and Falls (1965) and Fisler (1967) have suggested that homing is mainly the result of directed movements within familiar territory (the life range). Murie (1963) suggested that the homing he observed was the result of random wandering from the point of release. Griffo (1961) theorized that homing animals wander till they strike familiar territory, then utilize directed movements to reach their home areas. However, Burt (1940) and Bovet (1972) have suggested that some orientational ability is involved, 
enabling animals to achieve return by directed movements through unfamiliar territory.

Virtually no work has as yet been done to determine experimentally the degree of involvement of the various senses in homing behavior. Sheppe (1965) observed that mice (P. leucopus) would only leave the islands to which they had been transferred if they had visual goals toward which to orient. Mackintosh (1973) found that Mus musculus used visual cues to determine territorial boundary locations. Such landmarks might be used by mice in homing orientation.

The purpose of this study was to determine whether $\underline{P}$. Ieucopus noveboracensis are capable of return to their home areas once displaced, and the influence which distance has upon successful return. Further, I wished to test directly the involvement of vision in homing success both when the mice were released proximate to their home areas, and when released clearly off their home areas. 
THE STUDY AREA

This study was carried out in the area surrounding the Iaboratory of Endocrinology and Population Ecology of the College of William and Mary located on S. Henry Street in Williamsburg, Virginia.

The experiments were conducted on two areas (Fig. 1), which had been undisturbed for many years. In Plot I, the common trees were wild black cherry (Prunus serotina Ehrh), tree of heaven (Ailanthus eltissima (Miller) Swingle), red mulberry (Morus rubra L.), red maple (Acer rubrum L.), and some slippery elm (Ulmus mubra MuhI.). Along the ravine which ran through the area large white oak (Quercus a]ba L.), black oak (Quercus velutina Iam.), American elm (Ulmus americana L.), red maple, and persimmon (Diospyros virginiana L.) were found. Dogwood (Cornus florida L.) was the principle understory tree. Honeysuckle (Ionicera japonica Thunberg) and poison ivy (Rhus radicans L.) were common vines. Spicebush (Iindera benzoin L.), privet hedge (Iigustrum sp.), and stinging nettle (Urtica dioica I.) were found in a few small areas. The north-east section of Plot II is a floodplain with numerous southern red oak (Quercus rubra L.), and lesser numbers of hickory (Carya sp.), sycamore (Platanus occidentalis L.), loblolly pine (Pinus taeda L.), American elm, and some red maple. A few tulip trees (Liriodendron tulipifera L.), and paw paws 
(Asimina triloba L.) constituted the understory. The floor of the plain supported several large sycamores, many small red maples, and much jewel weed (Impatiens capensis Meerb.). On the more elevated southern section of the plot tree of heaven was very common. Wild grape (Vitis sp.) was frequently found and many small sycamores were present. A few pokeweed (Phytolacca americana I.), hackberry (Celtis occidentalis L.), and American elm were found. 


\section{GENERAI PROCEDURES}

In each area a trapping grid approximately 10,000 square meters in size was set up, consisting of six lines (A-F) with six trapping stations in each line. Iines and trap stations were spaced twenty meters apart, and marked by four foot aluminum stakes. Two single entrance live traps measuring $23 / 8^{\prime \prime} \times 3^{\prime \prime} \times 10^{\prime \prime}$ were placed within a radius of four meters of each stake. The traps had a gravity fall aluminum door and lock on one end, and $\frac{1}{4}$ inch hardware cloth on the opposite end. The sides and top were made of aluminum while the floor and treadle were made of wood, which reduced conduction of heat from the animals trapped. Traps at approximately $\frac{1}{2}$ the trap stations were covered with $12^{\prime \prime} \times 18^{\prime \prime}$ pieces of asphalt roofing. Three to four pellets of D \& G Laboratory Diet were kept in each trap, and the condition of the bait was checked every 3 days in hot humid weather and every 7 days in cold weather. When the night temperatures regularly dropped below freezing, cotton was placed in each trap and all remaining traps were covered with roofing.

Trapping periods were 15 days long. All animals were given a number by toe-clipping when first captured, and the animal's number, reproductive status (scrotal condition of males, vaginal opening, prognancy, and lactation of females) and location was noted at each capture. During the first 8 days of the trapping perlod (the removal phase), all animals with at least one previous 
capture were taken to the laboratory, weighed, and kept in standard plastic mouse cages. They were given D \& G Iaboratory Diet and water and were kept on a natural day-night cycle by means of the light from a laboratory window. At $\frac{1}{2}$ hour past sunset on the eighth day of trapping all mice were released as described in each experiment. During the 9th through the 15th day of trapping (the recovery phase) all mice were immediately released at the site of capture after the necessary data were recorded. The same general procedure was followed in all 5 experiments described below with exceptions noted for each.

Homing was defined as capture of a mouse at a trap station at which it had been previously captured or at an adjacent trap station. 
SPECIFIC EXPERIMENTAL PROCEDURES AND RESULTS

\section{Experiment I}

The purpose of the first experiment was to determine if $\underline{P}$. Ieucopus was capable of homing from approximately 671 meters, the distance between the centers of the two plots. Preliminary trapping was done for three days prior to the first trapping period in order to establish the identity and location of mice in the two areas (Table 1). The standard 15 day trapping period was conducted twice in succession. Mice taken from a given plot were released at trap station $\mathrm{C} 3$ on the opposite plot following retention in the laboratory. Homing performance was compared with that expected by random wandering. The number of mice expected to return by random wandering was calculated by measuring the section of a 360 degree arc which was delimited by lines drawn from the center of each field to the outer edges of the opposite field (Fig. 1). The two angles thus obtained were added, and the total was divided by 360 . The resultant percentage was multiplied by the number of releases to obtain the number expected to home as a result of random wandering.

\section{Results}

Twenty-seven different mice were released in this experiment, 
Table 1. Dates of the beginning and the end of each trapping period.

\begin{tabular}{lllll}
\hline & & & & \\
\hline & & & \\
& & & \\
& & & \\
Experiment: period & & & \\
Preliminary & trapping & $8-1-73$ & & $8-3-73$ \\
I & 1 & $8-4-73$ & $8-11-73$ & $8-18-73$ \\
& 2 & $8-19-73$ & $8-26-73$ & $9-2-73$ \\
II & 3 & $9-7-73$ & $9-14-73$ & $9-21-73$ \\
III & 4 & $9-25-73$ & $10-2-73$ & $10-9-73$ \\
& 5 & $10-13-73$ & $10-20-73$ & $10-27-73$ \\
& 6 & $10-30-73$ & $11-6-73$ & $11-13-73$ \\
IV & 7 & $11-17-73$ & $11-24-73$ & $12-1-73$ \\
& 10 & $1-14-74$ & $1-21-74$ & $1-28-74$ \\
V & 8 & $12-5-73$ & $12-12-73$ & $12-19-73$ \\
& 9 & $12-27-73$ & $1-3-74$ & $1-10-74$ \\
\hline
\end{tabular}


Figure 1. Aerial view of the study areas.

Key:

I : Plot I

II : Plot II

M : Release point midway between plots

$a, b, c, d$ : angles used in calculations performed below

Calculation of probable return by random wandering:

Experiment I : $\frac{c+d}{360} \quad X \quad$ Number of mice released

Experiment II $: \frac{a+b}{360} \quad X \quad$ Number of mice released 


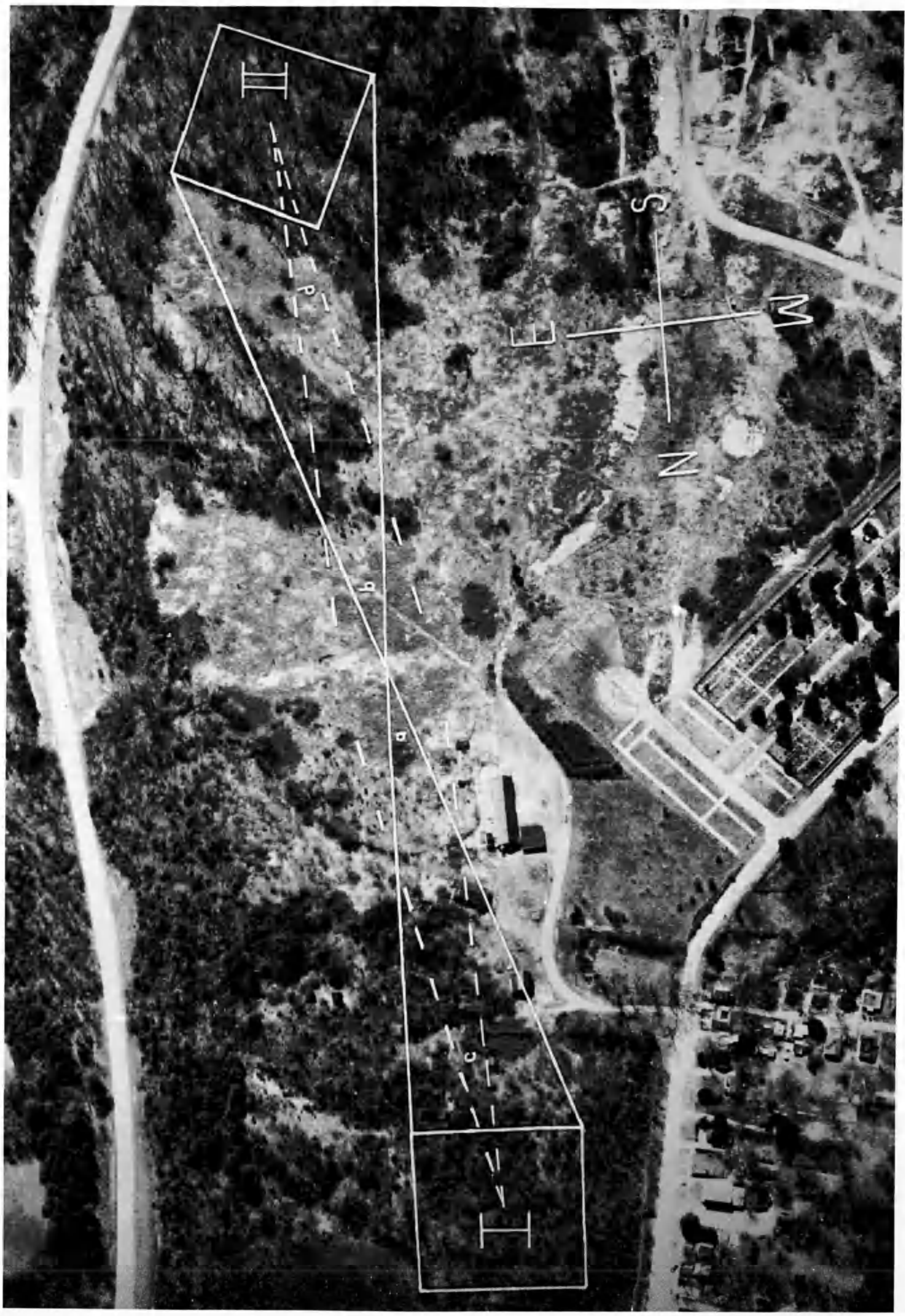


7 of which were released in both the 1st and the 2nd period, making a total of 34 releases (Table 2). Two mice homed, one during each period, and a third mouse returned to the correct plot in each period, making a total of 4 returns to the correct plu.

In 20 . of the 34 releases the mice were subsequently caught at least once in the plot where released and may have resettled. In 10 of the releases, the mice transferred were not recovered during the recovery phase. Neither the homing performance nor the return to the plot were found to differ significantly from that expected by chance. In order to eliminate the effects of experience the first release of each animal was considered. Two mice homed and one other returned to the correct plot out of a tatal of 27 nice transferied. Neither return to the plot nor homing were found to be significantly different than expected by random wandering. Firteen mice were recaptured during periods of Experiments I or II subsequent to the period in which they were transferred, and had therefore remained on the plots for at least 8 days.

\section{Experiment II}

The purpose of this experiment was to see how many mice would home if released on the same plot where captured. One trapping period was conducted; the release point was trap station C3 on the plot of capture (Fig. 1). 


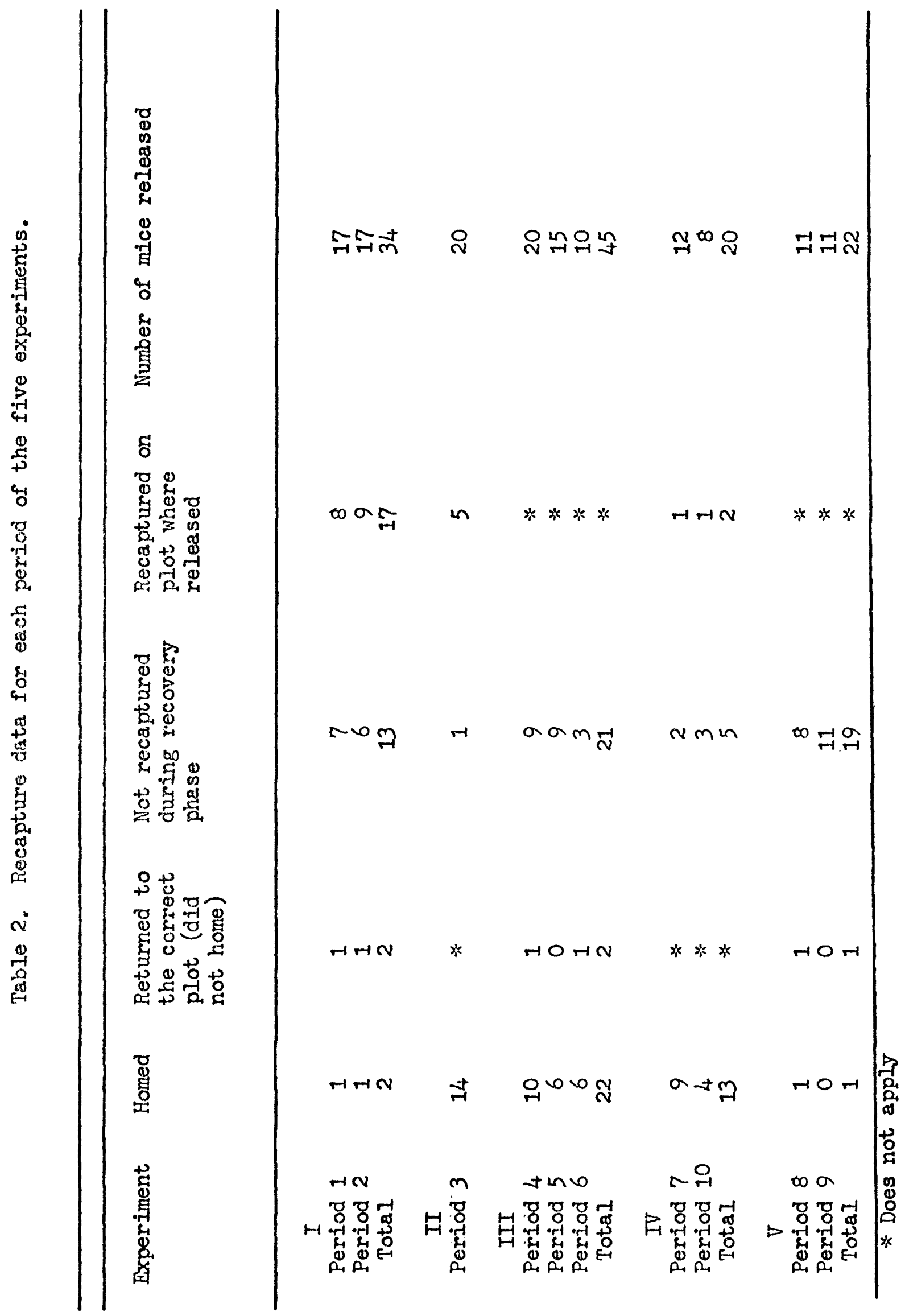


Results

Of a total of 20 mice released, 14 homed and 5 were subsequently captured elsewhere on the home plot (Table 2). No mice were trapped on the incorrect plot, and one mouse was not recovered during the recovery phase. This gives a homing rate of $70 \%$, and a non-recovery rate of $5 \%$

\section{Experiment III}

This experiment was conducted to see if the homing performance of $\underline{P}$. leucopus was altered by halving the return distance (the displacement distance) used in Experiment I; the relcase point was halfway between the centers of the two plots, and was in old field habitat where pines were just beginning to invade (Fig. 1), contrasting sharply with the wooded study areas. Three trapping periods ( 4,5 and 6$)$ were conducted, but due to an error the last trapping period (6) was only 14 days instead of 15. During this period the mice were released after 7 days of trapping.

\section{Results}

There was a total of 45 releases, involving 33 individual mice. Twenty-two releases resulted in homing, and 2 others resulted In return to the correct plot (Table 2), giving a total of 24 returns to the correct plot. The same procedure was used to estimate return expected by random wandering as in Experiment $I$, 
except the probabilities were calculated based upon angles obtained by drawing lines from the release point to the outer edges of both fields (Fig. 1). The data for both homing and return to the plot were found to be highly significantly greater than that expected by random wandering $(X=48, P<.001)$.

\section{Experiment IV}

This experiment was an attempt to measure the influence of vision on homing. Consequently the homing performance of blinded mice released on the capture plot was compared with that of the intact mice in Experiment II. Two trapping periods were conducted. AII mice captured during the first six days were blinded on the seventh day. Those captured on the seventh and eighth days were blinded at midday on the eighth day. All mice were released at trap station $\mathrm{C} 3$ on their plot of capture.

The blinding procedure was as follows. The mice were anesthesized with ether, the optic sclera was punctured with forceps, and the optic nerve was isolated, then cut with microscissors. The surgical area was washed with Zepharin, and the mice were returned to their cages. Mice recovered in the field were examined for gross morphological changes in the eyes as an indication of blinding; a grey spot in the eye, opacity or shriveling of the eye were all taken to indicate blindness. This technique of blindIng was proven to be effective in previous work (C. R. T'erman, personal communication). 


\section{Results}

Thirteen of the 20 mice homed (Table 2). This performance was not significantly different than that in Experiment II, in which intact mice were used.

\section{Experiment $\mathrm{V}$}

The purpose of this experiment was to determine the effect of blinding on the homing performance of mice released midway between plots as in Fxperiment III. Results were compared with those obtained in Experiment III and with chance. The procedure was the same as that in Experiment IV, with the exception of the release point. Probability of homing by random wandering was calculated as in Experiment III. Two trapping periods were conducted ( 7 and 10).

\section{Results}

There was a total of 22 releases, of which 1 resulted in homing and 1 resulted in return to the correct plot (Table 2). Neither of these results differed significantly from the number expected to return due to random wandering. Homing success was significantly less than that for intact mice in Experiment III $(X=10.9, P<.05)$. One mouse was captured on the incorrect plot during the same time. Of the 22 releases, 19 involved mice that were not recaptured during the recovery phase of the appropriate period. 
EFFECT OF VARIABLES

\section{Experience}

In Experiment III, 14 mice homed of the 33 never previously released between plots, and 7 of 12 mice with midpoint experience homed (Table 3). Thus experience from repeated release at the midpoint did not significantly improve the percentage of mice hoining. However, using the Kolomogorov-Smimoff test, I found that mice with previous midpoint experience did home significantly faster (Fig. 2). There was no significant difference between the homing of naive mice, and mice which had been released in any of Experiments I, II, and III (Table 3).

\section{Age}

Nineteen of the 38 releases of adults in Experiment III resulted in homing (Table 4). Three of the 5 releases of subadults resulted in homing, and neither of the 2 juveniles homed. There is no significant difference in the proportion of homing between any of the age classes. 
Table 3. Effect of multiple transfer on success of homing in Experiment III.

\begin{tabular}{lccl}
\hline & Naive mice & $\begin{array}{l}\text { Mice which had } \\
\text { previously been } \\
\text { released at the } \\
\text { midpoint }\end{array}$ & $\begin{array}{l}\text { Mice which had pre- } \\
\text { in Experiment I, II or } \\
\text { III }\end{array}$ \\
Homed & 14 & 7 & 14 \\
Did not home & 19 & 5 & 10 \\
\hline
\end{tabular}


Table 4. Homing performances of adults, subadults, and juveniles relessed during Experiment III.

\begin{tabular}{lccc}
\hline Age category & Homed & Did not home & Total \\
\hline AduIts & 19 & 19 & 38 \\
Subadults & 3 & 2 & 5 \\
Juveniles & 0 & 2 & 2 \\
\hline
\end{tabular}


Figure 2. Cumulative percentage curve showing the time taken for successful return by experienced and by inexperienced mice in Experiment III.

Experience is defined as previous release from the point midway between plots. 


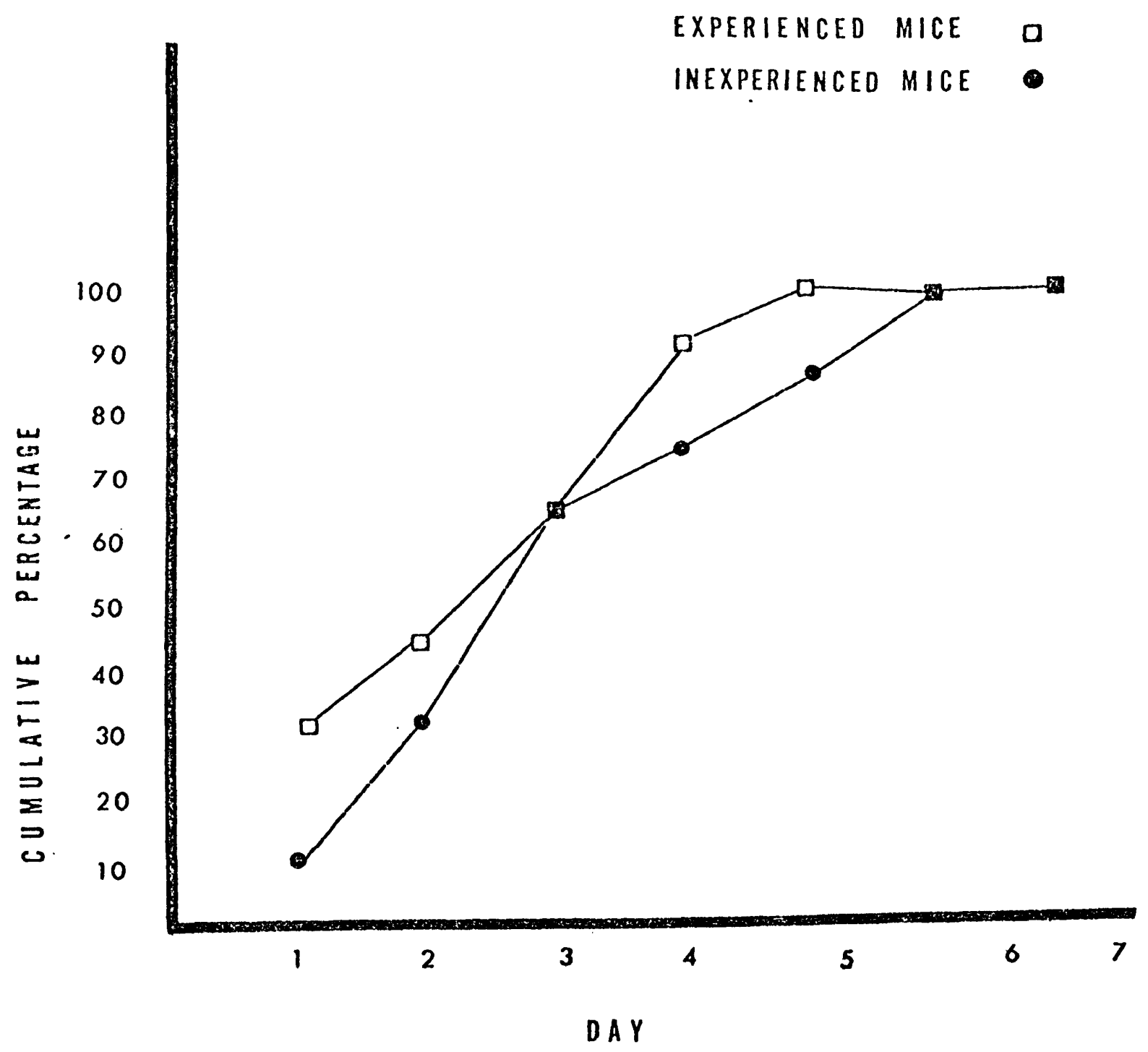


Sixteen of the 31 releases of males in Experiment III resulted in homing. Six of 14 releases of females resulted in homing (Table 5). Neither sex had a significantly better homing performance.

The numbers of males and of females transferred during each period of the five experiments are shown in Figure 3.

\section{Survival}

I tested survival of intact controls in Experiment II versus blinded controls in Experiment IV by determining the percentage of mice released on the plots of capture which were recaptured during the entire recovery phase and during the last three days of this phase. In Fxperiment II, 19 of the 20 intact mice released were recaptured during the appropriate recovery phase. During Experiment IV, 15 of the 20 blinded animals released were recovered (Table 6). Considering just the last three days of each period, 12 of 20 mice were recaptured in Experiment II, and 9 of 20 blinded mice were recaptured in Experiment IV (Table 7). There is no significant difference between the recapture rates of the two experiments for either time interval. 
Table 5. Homing performances of males and females in Experiment III.

\begin{tabular}{lccc}
\hline Sex & Homed & Did not home & Total \\
\hline Femele & 6 & 8 & 14 \\
Mele & 16 & 15 & 31 \\
\hline
\end{tabular}


Table 6. Number of mice released and recaptured during the seven day recapture phase of each period of the five experiments.

\begin{tabular}{cccc}
\hline Experiment & Number released & Number recovered & $\begin{array}{c}\text { percentage of } \\
\text { mice released } \\
\text { which were } \\
\text { recovered }\end{array}$ \\
\hline I & 34 & 22 & 64.7 \\
II & 20 & 19 & 95 \\
III & 45 & 24 & 53.3 \\
IV & 20 & 15 & 75 \\
V & 22 & 3 & 13.6 \\
\hline
\end{tabular}




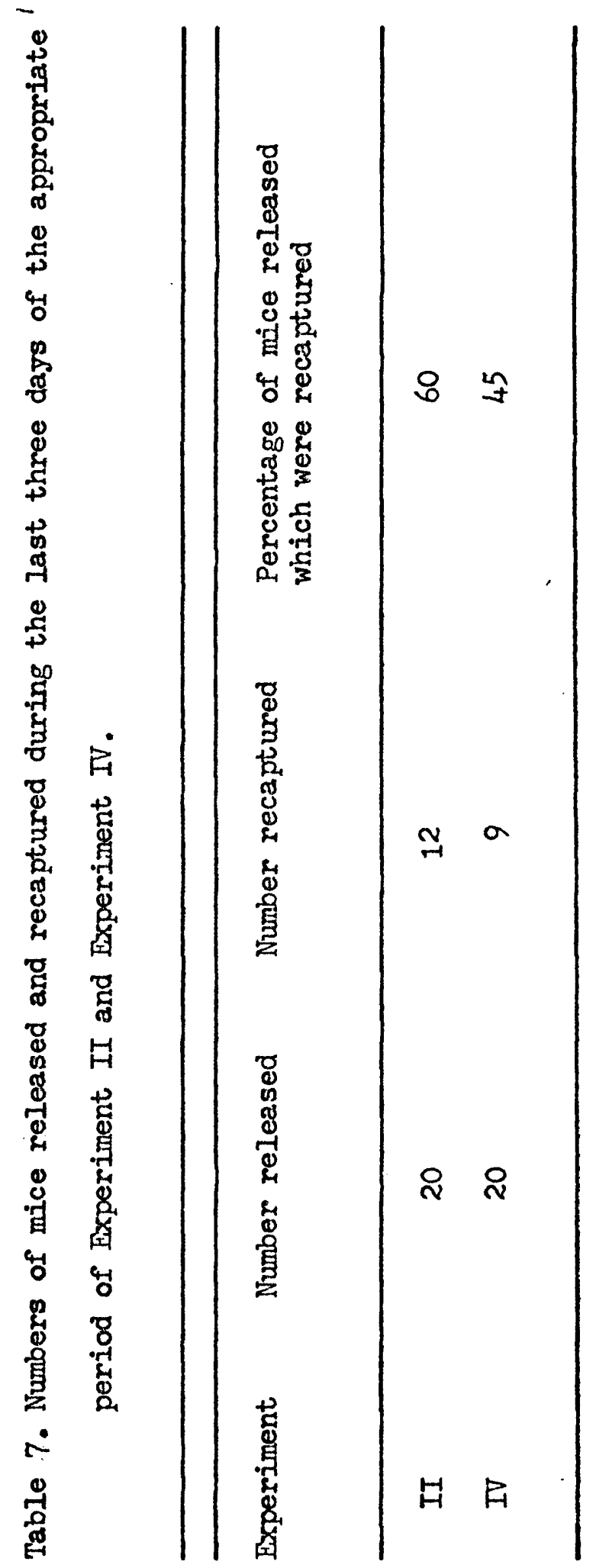


Figure 3. Numbers of males and females transferred during each peroiod. 


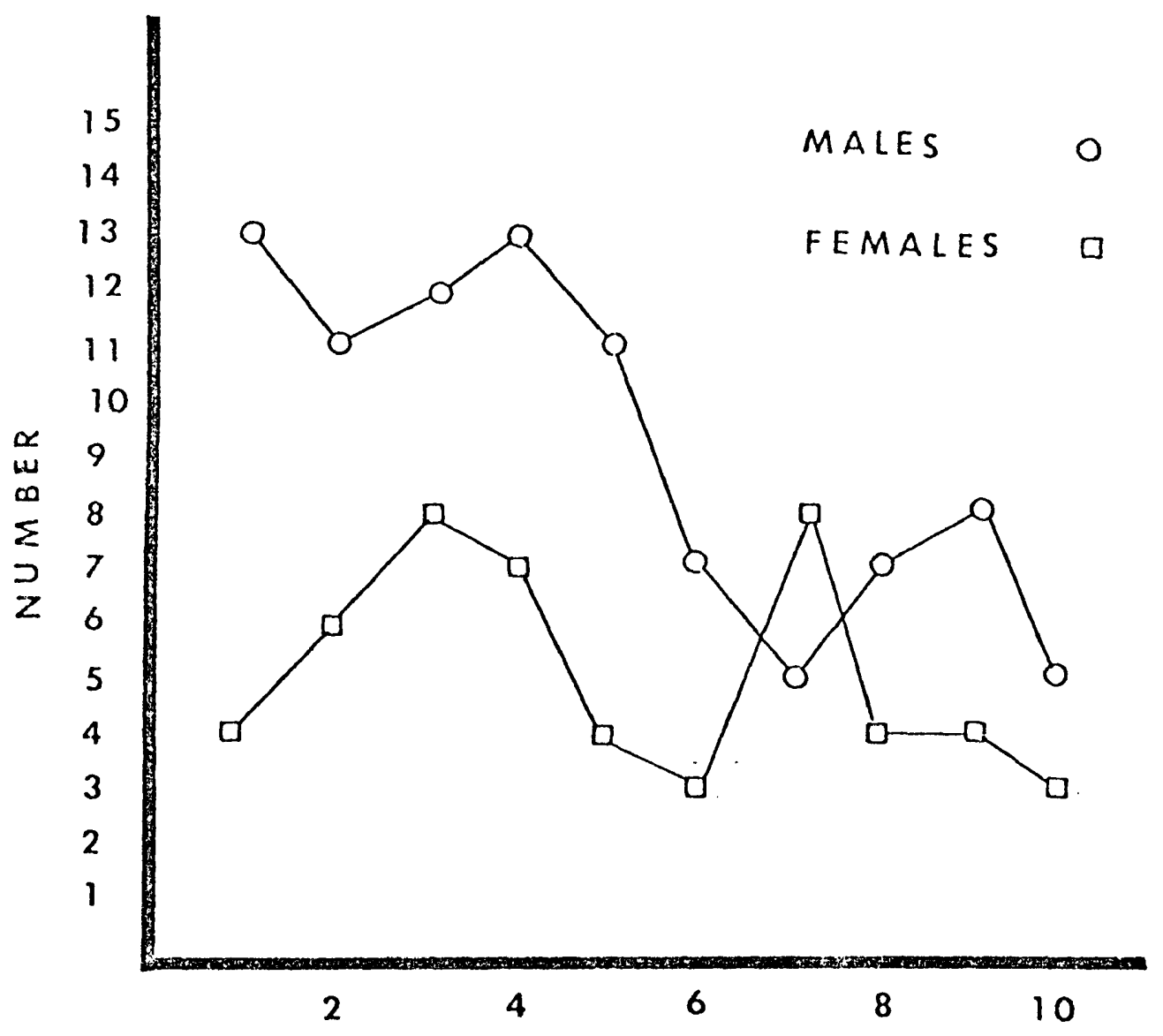

PERIOD 
Direction of Return Route

No significant differences were found in homing performances

to either Plot I or Plot II during Experiments I or III. 


\section{POPULATION DESCRIPTION}

The number of mice captured on Plot I and on PIot II are given in Table 8. Figure 4 shows that though Plot I had a consistently higher density, a decline in density during the course of the experiments occurred on both plots. Plot I appeared to have more undergrowth; this may have been a factor in its higher population density sirce Myton (1974) showed that density of $\underline{P}$. leucopus was related to the amount of undergrowth present.

Tables 9-11 give the age, sex, and reproductive rate of all the mice captured on PIot I and PIot II during each of the ten trapping periods. The same data are also represented in Figures 5-7. Age categories were determined by pelage color; juveniles with grey pelage; subadults with grey pelage being replaced by brown; and adults with brown pelage (Bendell 1959).

The age composition of the combined populations of Plot I and Plot II is presented in Figure 5. These data suggest that the population decline may have been due to the disappearance of adults, since subadults and juveniles appeared to remain fairly constant in numbers. The decline in the numbers of adults trapped may have been influenced by the experimental manipulations. 
Table 8. Numbers of mice captured on each plot during the removal phase of each period.

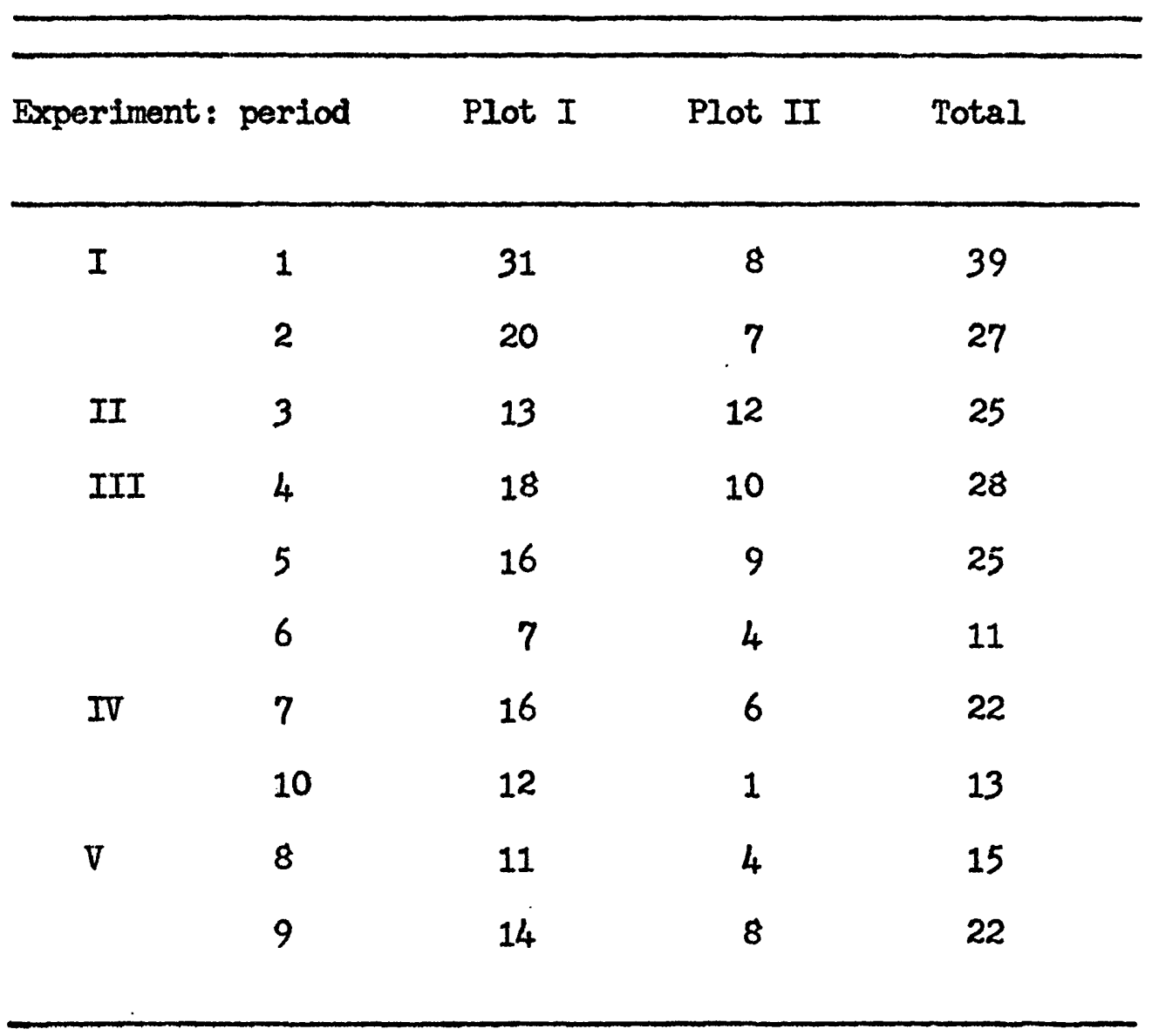


Table 9. Numbers of adults, subadults, and juveniles captured on Plot I and Plot II during each trapping period.

Experiment: period AduIts Subadults Juveniles

I

1

5

0

$\begin{array}{lllll}2 & 38 & 8 & 5\end{array}$

II $\begin{array}{lllll}3 & 3 & 28 & 6 & 1\end{array}$

III $4 \quad 30 \quad 5 \quad 4$

$5 \quad 24 \quad 9 \quad 1$

$\begin{array}{llll}6 & 10 & 7 & 1\end{array}$

IV $\quad \begin{array}{llll}7 & 9 & 17 & 4\end{array}$

$\begin{array}{llll}10 & 16 & 8 & 1\end{array}$

$\begin{array}{lllll}\mathrm{V} & 8 & 211 & 7 & 1\end{array}$

$9 \quad 14 \quad 11 \quad 2$




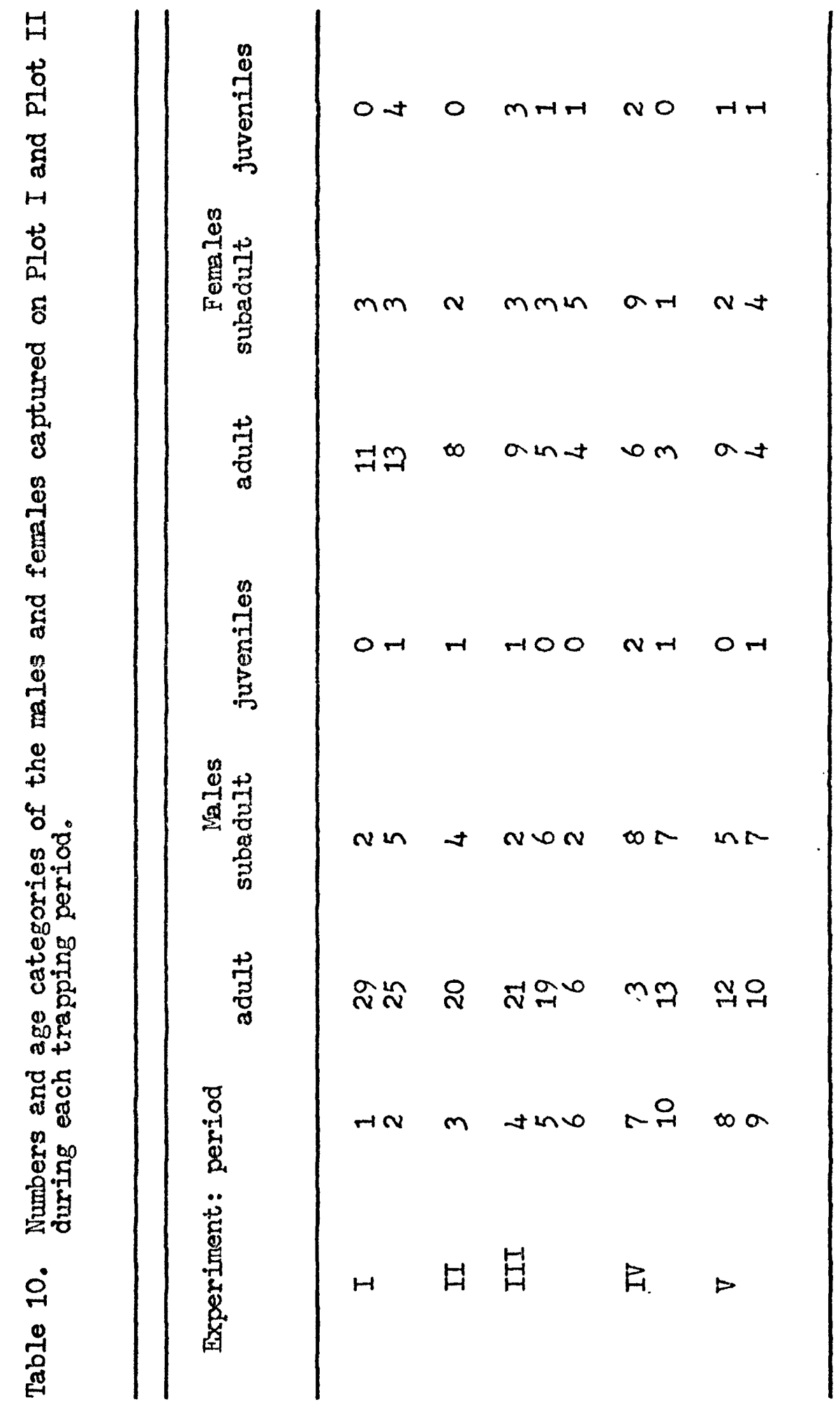


Table 11. Reproductive rate of the combined populations of Plot I and Plot II during each period.

Experiment: period

Reproductive rate

\begin{tabular}{llc}
$I$ & 1 & .73 \\
II & 2 & .54 \\
III & 3 & .38 \\
& 4 & .78 \\
IV & 5 & .40 \\
& 6 & .75 \\
V & 7 & .67 \\
& 10 & 1.0 \\
& 8 & .75 \\
\hline
\end{tabular}

* Reproductive rate: pregnant and/or lactating adult females divided by the total number of adult females 
Fj.gure 4. Numbers of mice captured on Plot $I$ and on Plot II during each period. 


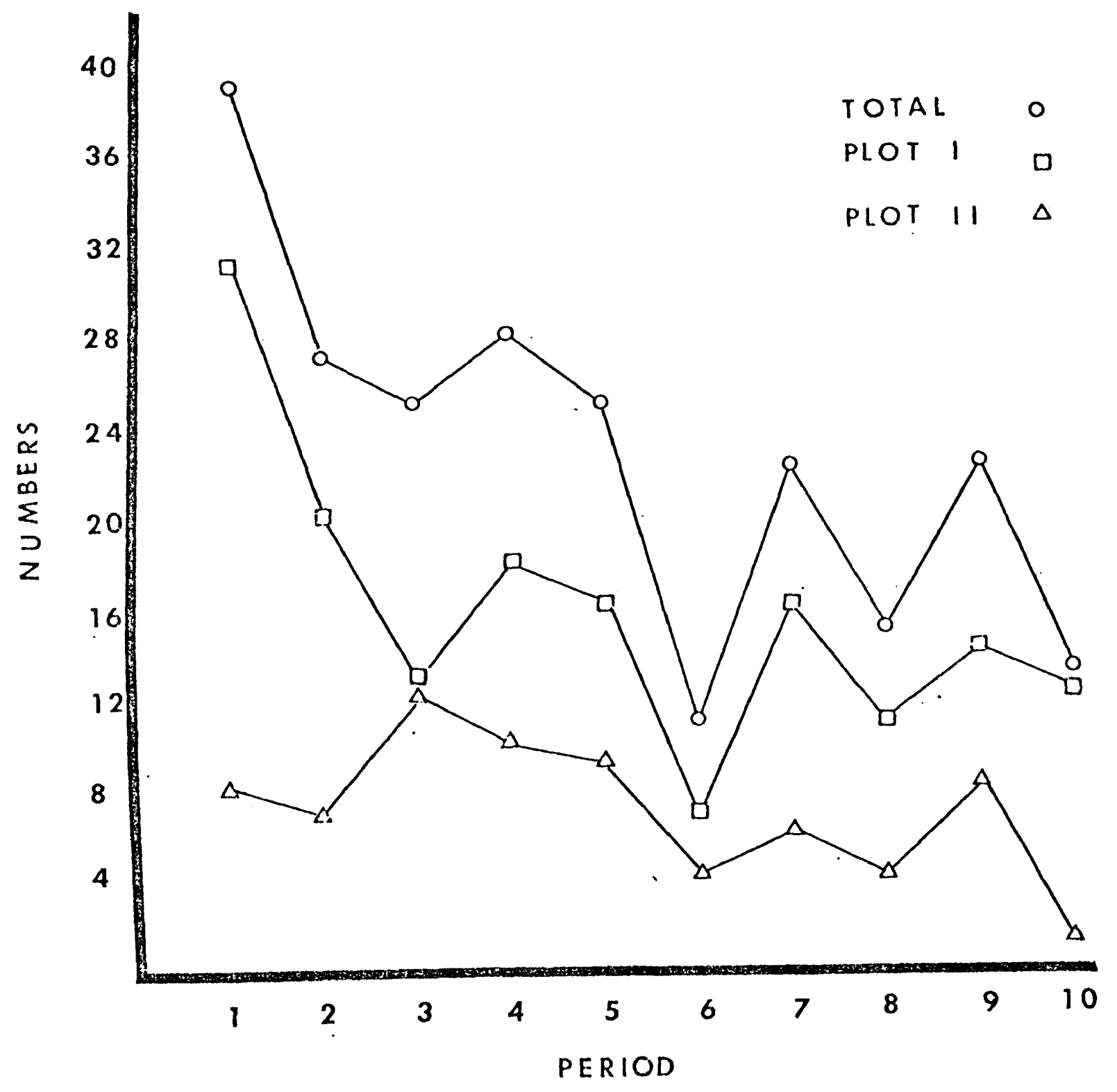


Figure 5. Numbers of adults, subadults, and juveniles captured on Plot I and Plot II during each period of the five experiments. 


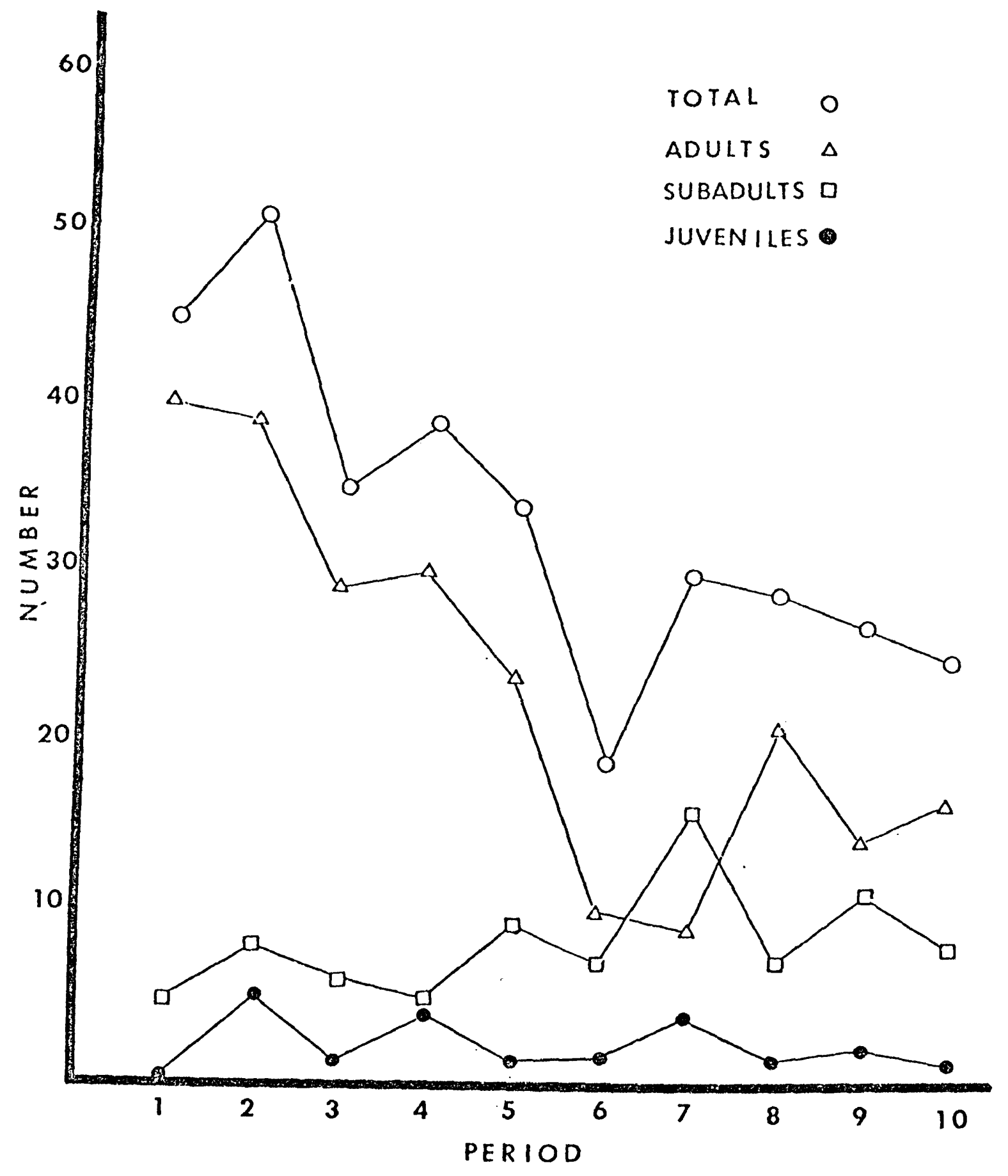


The sex composition of the total number of mice trapped on Plot I and Plot II is presented in Figure 6. The proportion of males declined during the early part of the study, whereas the proportion of females declined during the last three periods. The reason for this differential capture is not known.

Figure 7 shows the reproductive rate to have fluctuated widely during the experiments with no discernible trends. Reproductive rate was defined as the number of pregnant and/or lactating adult females divided by the total number of adult females captured. 
Figure 6. Numbers of males and femsles captured on Plot I and Plot II during each period of the five experiments. 


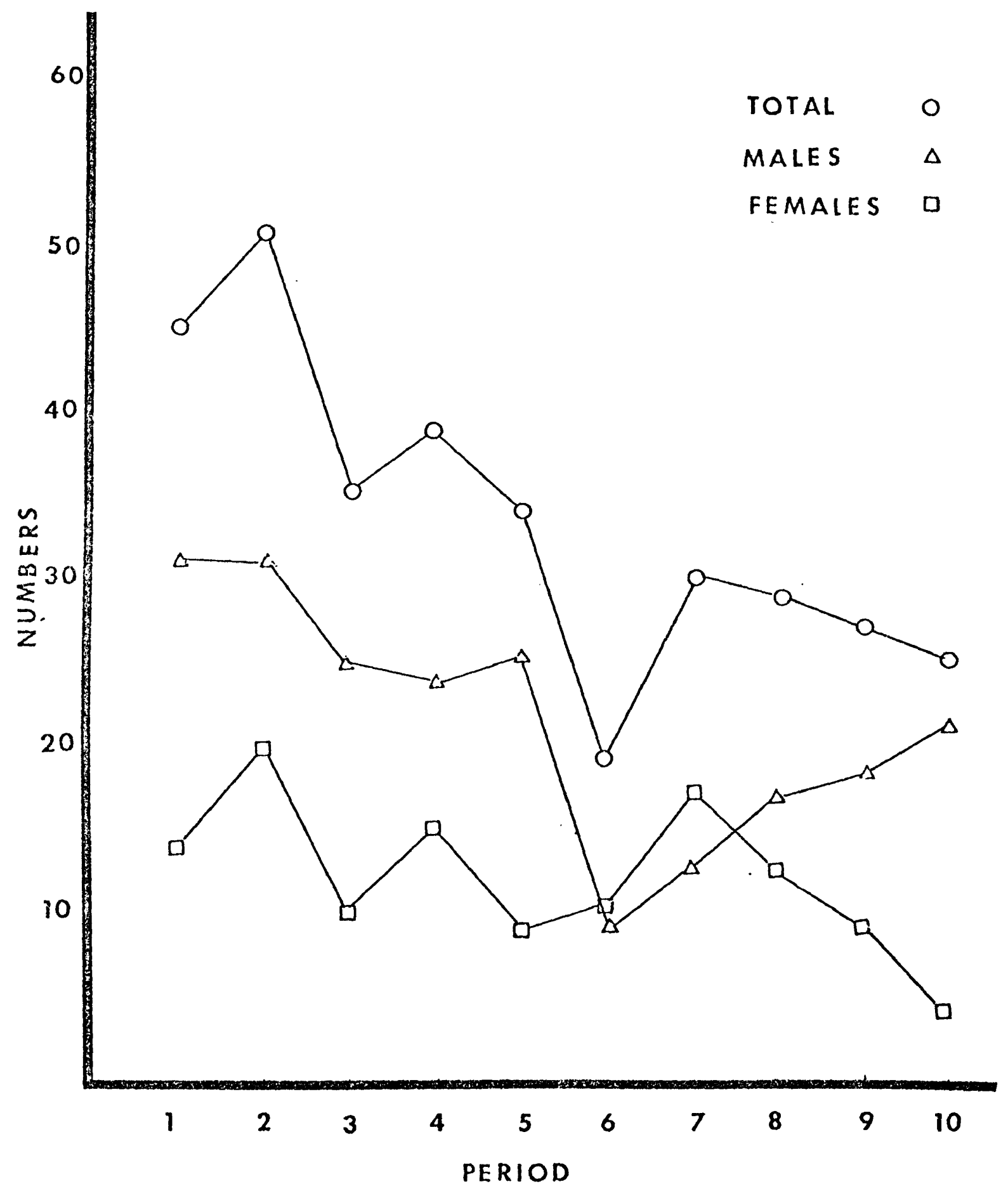


Figure 7.: Reproductive rate of the mice captured on Plot I and Plot II during each period of the five experiments.

Reproductive rate was calculated by dividing the number of pregnant and/or lactating adult females by the total number of adult females captured (during each period) 


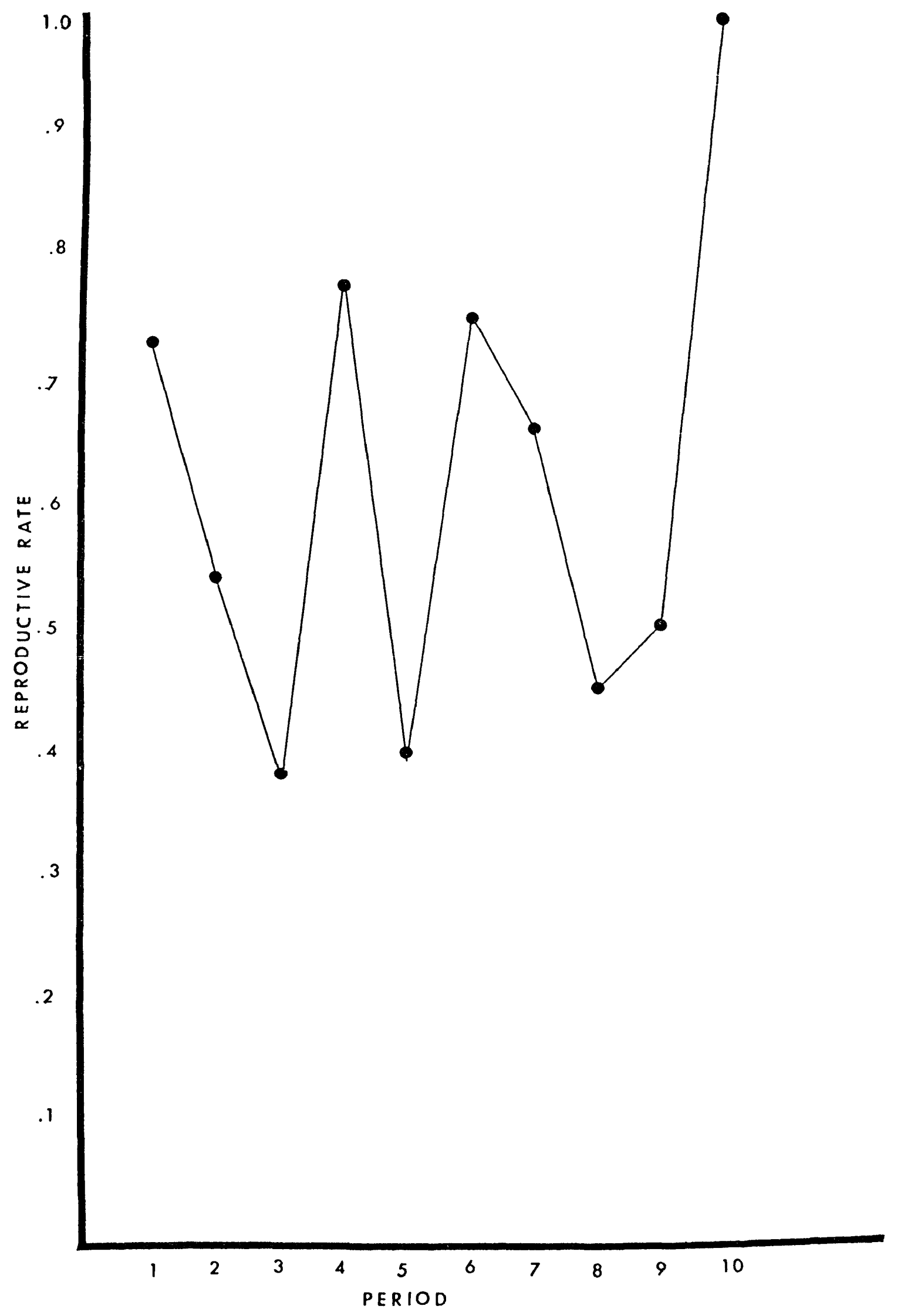




\section{DISCUSSION}

In this study of the white-footed mouse, homing performance was shown to be inversely distance dependent. In Experiment II, intact mice were displaced an average of 671 meters, and their homing performances were not significantly different that those expected as a result of random wandering. Seventy percent of the intact mice released within the plot where captured homed, while ninety-five percent were recaptured at some point within the home plot. The latter percentage was the maximum recapture percentage of transferred mice.

Several. studies have shown that the percentage of small mamals homing declines relative to the distance the animals are displaced from the capture point (Murie 1963, Robinson and Fallo 1965, Griffo 1961, Stickel 1949, Hacker and Pearson 1951, Bovet 1972). Bovet (1972) displaced Peromyscus maniculatus short distances of 175 and 400 meters and intermediate distances of 650 and 735 meters. These distances were comparable to my distances of 336 and 671 meters. He found a significantly smaller percentage of mice homing at the longer distances, 8.s was also true in my study. Further increasing the distance to 950 meters did not result in an additional si-gnificant decline in homing success (Bovet 1972). While homing performance appears to be inversely related to displacement distance 
In my study, there may not be a linear relationship between the two factors; i.e. there could be a threshold effect. Furrer (1973), working with $\underline{P}$. maniculatus, found that at displacement distances of up to approximately 150 meters homing success declined about 10-15\%. This decline was attributed to a lack of homing by animals without homing motivation, such as transients. From about 200 meters to about 600 meters there was a gradual decline in homing success. At about 600 meters the homing percentage once again dropped sharply, possibly due to the mice having been released outside their life ranges (Furrer 1973). Homing from shorter distances was possible because the animals were familiar with a life range considerably larger than their home ranges. Testing at additional distances would show whether $\underline{P}$. leucopus followed a similar pattern. Experience in an area has been suggested to increase an animaj.'s abijity to orient itself and to home (Robinson and Falls 1965, Fisier 1962). Repeated releases from the same point would be expected to improve performances in both speed of return and success of homing. However, in Experiment III I did not find a significant difference in homing performance between mice released for the first time midway between plots, and those which had had at least one previous midpoint release. Further, no significant difference in homing performance was found between mice released for the first time and those released previously in any of the periods of Experiments I, II, or III. Thus neither experience in the specific area nor anything associated with being transferred in itself appeared to have a significant effect on homing. It might be argued that mice 
used in the experiments were already familiar with the area so further experience would not be expected to result in improved homing performance. Results from the blinding experiments discussed later, and the fact that the area surrounding the midpoint release is an old field rather than woods, argue against this possibility. P. leucopus is a semi-arboreal species which is generally found in woods (Baker 1968) and would be unlikely to venture into field habitat.

Experience did affect speed of return of mice after release midway beiween plots (Experiment III). Significantly more experienced mice than inexperienced homed within one day following release $(P<.05)$. The mice may be able to distinguish the general direction of return without experience but may learn a specific trail after transfer, improving speed of return.

No significant differences were found in return to either PIot I or PIot II. This suggests that neither the compass orientation to the plot nor topography were differentially influential in channeling the mice toward their home areas.

Any tendency to settle in the release area could greatly influence homing performance. Fisler (1962) found that some Microtus califomicus would remain where released, and therefore suggested that intraspecific social factors were the major motivation for voles leaving the release areas rather than any drive to return home. However Bovet (1972), working with P. maniculatus, found that the same proportion of mice were recaptured in the release aress at all of his displacement distances. Therefore factors operating during return rather than resettlement were responsible 
for his differences in homing success. In my study, 15 of the mice In Experiment I were recaptured at least 8 days after release in the plot to which they had been transferred, a fact suggestive of es-tablishment. This may be related to the fact that the population density had been lowered during the removal phase of each period. Healey (1967), working with P. maniculatus austerus, found inmigrants to be more successful in establishing themselves on plots from which the residents had been removed than on plots which still had their resident populations. Thus one reason most mice in Experiment I did not home might be because they had suitable home ranges available. However, the proportion of recaptures in Experiment. I was less than that in Experiment II where mice were released on the plots where captured, although not significantly so. Assuming that the plots were depleted of mice to the same extent in both experiments, it may be that the mice had a smaller tendency to disperse when released on the plot of capture and showed a greater attachment to their home areas. Griffo (1961) proposed that a psychological attachment to the home range may stimulate attempts to home. If such an attachment is operating it shows a distinct heterogeniety in the population, and it does not explain the means by which displaced animals find their way home.

Some of the most interesting data obtained in the experiments are those supplying information on the involvement of vision in homing. Although the homing performances of blinded mice released on the plot where captured were not significantly different from those of intact mice treated similarly (homing: blinded 65\%; intact $70 \%$ ), blinded mice were significantly less successful at homing than 
intact mice when released midway between plots. In fact, the homing performance: of blinded mice released at midpoint was almost exactly that expected by random wandering. This, combined with the fact that the release area was an old field, a habitat in which $\underline{P}$. leucopus is not normally found, suggests that the mice were not familiar with the release area. Intact mice would not be expected to be any more familiar with the area than blinded mice and their significantly better homing when Experiments III and V are compared indicates that vision was a jor factor in their navigation.

Vision has not been extensively studied in rodents. King and Vestal (1974) found that 5 species of Peromyscus, including p. leucopus, have a degree of visual acuity not greatly inferior to that possessed by primates. Bovet (1968) did not believe vision to be important to homing in rodents. However Sheppe (1965) found that P. leucopus, when transported to islands in Iake Opinicon, would only leave the islands (possibly in an attempt to home) if there were visual goals toward which to orient. Further, Mackintosh (1973) found that visual cues were the most important cues used by Nus musculus in locating territorial boundaries, and that olfactory cues were subordinate to visual ones. Although vision is probably more important than previously believed, it is still difficult to understand how small mammals in high grass use vision to find their way home, but my studies indicate that they do.

Possibly the mice utilize different senses for orientation on familiar and unfamiliar territory (Fig. 1), or on continuous and discontinuous habitats. Olfaction has been shown to be a major 
factor in rodent behavior. Mackintosh (1973) has shown that Mus musculus do use olfaction in locating territorial boundaries, although olfactory cues are subordinate to visual cues. Therefore mice released on their plot of capture, relatively close to their home areas, might resort to olfaction to re-establish themselves correctly. Archer (1968) found that strange male odor caused a slgnificant increase in aggression in pus musculus males. Jones and Nowell (1973b) found that familiar olfactory cues influenced aggression more than familiar visual ones and that coagulating gland secretion combined with bladder urine produced an aggression inhibiting and aversive pheromone in the male albino mouse (Jones and Eowell 1973a). Marking behavior can induce either avoidance or attraction in conspecifics depending upon the species, season, mood, sex, and age of the unimais involvea (Rottman and Snowdon 1972, Johnson 1973, Gleason and Reynierse 1969). Further, Moore (1965) found that olfactory discrimination maintained reproductive isolation between $\underline{P}$. maniculatus and $P$. polionotus Thus olfaction may be highly specific in its efiects (Jones and Nowell 1974) and has the potential for a very precise information vector. Olfaction could be an important sense relied upon for orientation on familiar terrain (or it might be the continuity of the habitat which is im-portant), while vision may have this function on unfamiliar territory. Further work is needed to clarify these possibilities. Griffo (1961) suggested mice wander randomly from the release point till they found familiar landmarks to guide them. This seems the most likely explanation for the results $I$ obtained in Experiment III as it requires the least number of assumptions about the mice's 
capabilities. The mice could have reached woods continuous with the areas of capture by wandering a short distance (Fig. 1). Approximately $\frac{1}{2}$ the mice released in Experiment III homed successfully. Approximately the same percentage of mice would be expected to reach the woods by random wandering. However, the manner in which vision would be involved is not immediately apparent. It might be important when the animals encountered wooded areas for recognition of terrain landmarks. In this case, it would mean that not the continuity but the familiarity determines which sense is vital to orientation, since blinded mice would be just as likely to reach the woods by random wandering as intact mice, but blinded mice still homed to a significantly smaller degree. The mice could also have used vision to direct themselves to the nearest group of trees, then homed. Since they nomelly live in a woods habjtat they might have a tendency to orient toward trees when they are released in an old field (an atypical habitat).

There may be an inverse relationship between the familiarity of the area and the permanence of the sense cue used. The results of the blinding experiments would correspond with the expected permanence of the sense cues in the field. Put more simply, the reason vision was apparently essential to successful return from the midpoint might have been because visual landmarks, such as trees, are quite stable. Other sense cues, such as olfactory ones, would not be expected to be as long lasting nor as stable in their location. Thus, returning from less familiar areas, ones in which the animals would not have been nearly as recently as in 
their own home areas, might require vision simply because visual cues are the only ones which are still recognizable. Although it is theoretically possible that sense cues are arranged in a hierarchy, with the most permanent type being the last one referred to, there is no data to support such a theory. I believe that it is more probable that the animals use whichever sense cue is recognized in the environment and orient themselves accordingly., At present I know of no proof for either theory.

Bovet (1972) and Burt (1940) velieved that the mice could achieve directed return through unknown terrain. In order to do this, some form of celestial navigation could be used. While this would certainly involve the use of vision, and would therefore agree with the data from the blinding experiments, it would also require that the animals possess rather high level abilities of perception and organization of environmental stimali (Wallraff 1960) which $\underline{P}$. Leucopus has not yet been shown to have. Since they are nocturnal animals (Behney 1936), they would probably use either the stars or the moon in navigating. To do this they would have to have an extremely accurate internal chronometer in order to allow for the movement of the celestial bodies with time. It would seem more reasonable to reject this explanation as long as a simpler one fits all the known facts. However, the possibility that mice are capable of celestial navigation should be examined. 
Refrences Cited

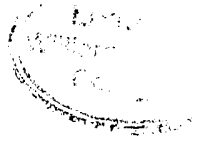


REFRENCES CITED

Archer, John. 1968. The effects of strange male odor on aggressive behavior in male mice. J. Mamm. 49: 572-575.

Baker, Rollin H. 1968. Habitats and distribution. In Biology of Peromyscus. King, J. A. (ed.), 98-126. Spec. Publ. Am. Soc. Nammal. No. 2.

Behney, W. H. 1936. Nocturnal explorations of the forest deermouse. J. Mamm. 17: 225-230.

Bendell, J. F. 1959. Food as a control of a population of whitefooted mice, Peromyscus leucopus noveboracensis (Fischer). Can. J. Zool. 37: 173-209.

Bovet, Jacques. 1968. Trails of deer mice (Peromyscus maniculatus) traveling on the snow while homing. J. Mamm. 49: 713-725.

- 1971. Initial orientation of deer mice (Peromyscus maniculatus) released on snow in homing experiments. Z. Tierpsychol. 28: 211-216.

- 1972. Displacement distance and quality of orientation in a homing experiment with deer mice (Peromyscus maniculatus). Can. J. Zool. 50: 845-853.

Boyd, J. M. 1963. Home range and homing experiments with the St. Kilda field-mouse. Proc. Zool. Soc. Lond. 140: 1-14.

Broadbrooks, Harold E. 1961. Homing behavior of deer mice and pocket mice. J. Mamm. 42: 416-417.

Burt, W. H. 1940. Territorial behavior and populations of some small mamnals in southern Michigan. Misc. Publ. Mus. Zool. Univ. Mich. 45: 1-58.

Fisler, George F. 1962. Homing in the California vole, Microtus californicus. Amer. Midl. Nat. 68: 357-368.

- 1967. An experimental analysis of orientation to the homesite in two rodent species. Can. J. Zool. 45: 261-268. 
Furrer, R. K. 1973. Homing of Peromyscus maniculatus in the Channelled Scablands of east-central Washington. J. Mamm. 54: 466-483.

Gentry, John B. 1964. Homing in the old-field mouse. J. Mamm. 45: 276-283.

Gleason, Kathryn K. and James H. Reynierse. 1969. The behavioral significance of pheromones in vertebrates. Psych. Bull. 71: 58-73.

Griffo, J. V. Jr. 1961. A study of homing in the cotton mouse, Peromyscus gossypinus. Amer. Midl. Nat. 65: 257-289.

Hacker, H. P. and H. S. Pearson. 1951. Distribution of the long tailed field mouse, Apodemus sylvaticus, on South Haven Peninsula, Dorset, in 1937, with some observations on its wandering and homing powers. J. Linn. Soc. Iond. 42: 1-17.

Healey, Michael. C. 1967. Aggression and self-regulation of population size in deermice. Ecol. 48: 377-392.

Johnson, Rodger P. 1973. Scent markings in mammals. Anim. Behav. 21: $521-535$.

Jones, R. B. and N. W. Nowell. 1973a. The coagulating glands as a source of aversive and aggression-inhibiting pheromone $(s)$ in the male albino mouse. Physiol. and Behav. 11: 455-462.

- 1973b. The effect of familiar visual and olfactory cues on the aggressive behavior of mice. Physiol, and Behav. 10: 221-223. - 1974. The urinary aversive pheromone of mice: species, strain and grouping effects. Anim. Behav, 22: 187-191.

King, John A. and Bedford M. Vestal. 1974. Visual Acuity of Peromyscus. J. Mamm. 55: 238-243.

Iayne, James N. 1957. Homing behavior of chipmunks in central New York. J. Namm. 38: 519-520.

Macabe, R. A. 1947. Homing of flying squirrels. J. Manm. 28: 404.

Mackintosh, J. H. 1973. Factors affecting the recognition of territory boundaries by mice (Mus musculus). Anim. Behav. 21: $464-470$.

Moore, Robert E. 1965. Olfactory discrimination as an isolating mechanism between Peronyscus maniculatus and Peromyscus polionotus. Amer. MidI. Nat. 73: 85-100. 
Murie, M. 1963. Homing and orientation of deermice. J. Mamm. $4 l_{4}: 338-349$.

Murie, 0. J. and Adolph Murie. 1931. Travels of Peromyscus. J. Mamm. 12: 200-209.

1932. Further notes on travels of Peromyscus. J. Mamm. 13: $78-79$.

Myton, Becky. 1974. Utilization of space by Peromyscus leucopus and other small mammals. Ecol. 55: 277-290.

Robinson, W. L. and J. B. Falls. 1965. A study of homing in meadow mice. Amer. Nidi. Nat. 73: 188-224.

Rottman, Steven J. and Charles T. Snowdon. 1972. Demonstration and analysis of an alarm pheromone in mice. J. Comp. Physiol. Psychol. 81: 483-490.

Sheppe, Walter. 1965. Dispersal by swimming in Peromyscus leucopus. J. Mamm. 46: 336-337.

Sticke1, I. F. 1949. An experiment on Peromyscus homing. Amer. Mid1. Nat. 41: 659-664.

Terman, C. Richard. 1962. Spatial and homing consequences of the introduction of aliens into semi-natural populations of prairie deermice. Ecol. 43: 216-223.

Wallraff, Hans G. 1960. Does celestial navigation exist in animals ? Cold Spring Harb. Symp. quant. Biol. 25: 451-461. 


\section{VITA}

Judith Ann Cooke

Born on January 21, 1947 in Somerset, Kentucky. Graduated from Hopewell High School in Hopewell, Virginia, June 1965. Received a B. S. degree from the College of William and Mary, Williamsburg, Virginia; June 1969. Entered the College of William and Nary for graduate studies September 1972. Worked as a Graduate Teaching Assistant 1972-1973. Currently a candidate for the degree of Master of Arts in Bjology. 